\title{
HISTORY AS A GUIDE TO EFICIENT CULTURAL STRATEGY
}

\author{
Katerina Papaioannou \\ University of Patras, GREECE, papaioannou.kat@gmail.com
}

\begin{abstract}
The primary objective of this study is to present a theoretical approach and analysis of the term "history". The study of history is of crucial importance for the transmission of culture and national values. Modern states should exploit the study of history, since only by acquiring historical consciousness will they be able to formulate new policies to promote and preserve their culture. Knowledge of the past leads to a better understanding of the facts of the present; therefore, it also enables a more accurate, efficient and - hopefully - globally beneficial planning of the future.
\end{abstract}

Nowadays, the purpose of history is to assist us in a two-fold way in order to: (i) better understand the present and deal with it responsibly through the knowledge and study of the past as well as (ii) to take the necessary initiatives and action for creating and preparing a better future. One could, therefore, claim that the main purpose of history is rather didactic than cognitive. Careful study of history contributes to a proper understanding of the present, resulting to states able to exploit their past and use it as a guide for shaping their national strategy and maximizing their present and future benefits in the contemporary global setting.

Keywords: History, culture, international relations.

\section{INTRODUCTION}

Our need to have knowledge of our past started very long ago, even before the invention and spread of writing. The narration of an event was of particular importance in speaking societies, as is known by Homeric epics. This is how Oral History - the first type of History - emerged whose role was catalytic for the transmission of information and knowledge. The term "oral history" can be considered "contemporary" because it is linked to the tape recorder technology, but in fact it is as old as the need of people to know their past. An excellent example of the use of oral evidence, after writing spread began, is contained in Thucydides' narrative. 


\section{WHAT IS HISTORY AND WHY WE STUDY IT}

History was established as a science in the 19th century due to the philosophical theory of positivism. In the 19th century, the novelty in the writing of history was that historical studies were professionalized and centralized in universities and research centers. Self-declaration of history as a discrete scientific field implied a strict separation between science and literature. The aim was to transpose universal laws in history, following a spirit similar to that of laws in formal and natural sciences. Positivists, wishing to substantiate their claim that history is science, placed special focus on events. They supported that events should be first verified and then used for reaching conclusions. The perception of history in the framework of positivism completely matched corresponding ideas of empiricism. Empiricism suggested the following approach to history: we should first verify events and then take the risk to interpret them. However, the approach of empiricism presented flaws and inefficiencies. Historical events should be clearly distinguished from simple events of the past. Events widely accepted by all historians formed the main criterion for this classification. Such events essentially induced a core around which history unfolds. However, despite the obvious requirement for accuracy regarding the described events, the selection of events is not based on some particular property but, instead, on an a priori decision of the historian which actually causes events to reveal. In the early 20th century a new philosophy of history was proclaimed by Croce ${ }^{1}$ according to which history actually constitutes a look at the past with the eyes of the present in the light of the current problems. This implies that the main task of the historian is to evaluate rather than record. This is because lack of evaluation makes a historian incapable of deciding what is worth recording and what is not. Croce's views influenced the British philosopher and historian Collingwood ${ }^{2}$, who suggested that the philosophy of history does not deal exclusively with "the past itself" or "the conception of the historian for the past itself", but, instead, with their mutual relationship. «The past studied by a historian is not a dead past, but a past which, in a certain sense, still lives in the present». Through the depiction of the different approaches and interpretations that have been attempted since the 19th century as to what is ultimately history, two poles are dominant, the fact and the interpretation. However, they can still be addressed in different ways like, for example, using approached which can be empirical or theoretical, objective or subjective. So, an answer to the question "What is history?" can be Edward Hallett Carr's ${ }^{3}$ statement that history is a continuous process of interaction between the historian and events, a unending dialogue between the present and the past (Carr, 2008, p. 18-59).

The way history is written - including issues that concern historiography - is not at all independent of the developments taking place in societies. According to Emile Durkheim ${ }^{4}$, we perceive the world and the reality - and, therefore, also history - through intellectual representations that we mentally compose. When these representations are generally accepted as correct and true in a community of people, they become a social fact, and, regardless of whether they are actually correct and/or true, they are treated as valid and form a cause of action by community members. History is therefore a social, interpretive and critical anthropological science closely linked to other social sciences, namely sociology, psychology, economics, political and legal sciences, and, in general, closely related to all fields of knowledge that are in fact disciplines of civilization (Picon, 1958, p. 9).

The purpose of history today is to provide us with the ability to better understand the present and to deal with it responsibly through the knowledge and study of the past, as well as to take the necessary steps to create and prepare a better future. We could claim that the main purpose of history is rather didactic than cognitive.

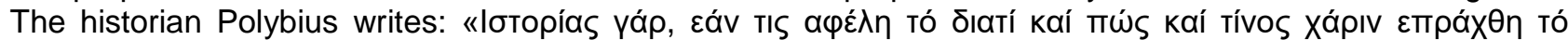

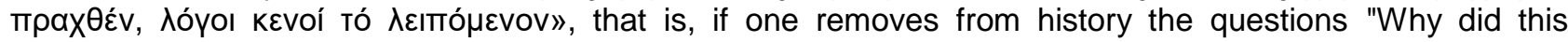
happen? How did this happen? What need did it serve?", then the rest of the words are void. The careful study of history provides an understanding of the present, so that states can exploit the past in order to design and implement their national identity strategy, maximizing their present and future benefits.

${ }^{1}$ Croce Benedetto (1866-1952). Italian philosopher, historian, critic and liberal politician. Founder of La Critica. Minister of Education in 1920-21, opposed the Mussolini regime.

${ }^{2}$ Collingwood Robin George (1889-1943). British philosopher, archaeologist and historian, professor at Oxford from 1934 to 1941.

${ }^{3}$ Carr Edward Hallett (1892-1982). British historian, diplomat, journalist, international relations theorist and opponent of empiricism through historiography.

${ }^{4}$ Emile Durkheim (1858-1917). French philosopher and sociologist considered to be one of the most important figures who contributed to the development and foundation of the science of sociology. 
Of particular importance is the part of history addressing culture, i.e., the history of culture. History of culture deals with the study of the spiritual, social and economic life of the peoples (in terms of science, technology, arts, language, traditions, customs, economy, political changes, etc.) with an objective to support states in shaping their cultural strategy (Picon, 1958, p. 401.).

\section{CONCLUSION}

Given the crucial role of history in the development of humanity both in terms of social structures as well as in terms of cultural identification, modern states should place special focus on exploiting the study of history. Only by acquiring historical consciousness and historically-critical spirit will modern states be able to formulate new policies to promote and preserve their culture. Knowledge of the past leads to a better understanding of the facts of the present and, thus, to a correct planning of the future both in terms of achieving social prosperity at a national level and gaining a strong position globally in a continuously changing international and regional setting.

\section{REFERENCE LIST}

Carr, E. H., 2008. What is History? Penguin Press, London, UK.

Picon, G. 1958. Panorama des idées Contemporaines, Librairie Gallimard, Paris, France. 